\title{
Comparative Study of Physical Education Students Teachers Style Interventions Teaching Styles Skill
}

\author{
Naila Bali, Khemais Souissi \\ University la Manouba, UMA, Tunis, Tunisia \\ Email: naila bali@yahoo.fr
}

Received 6 January 2015; accepted 25 January 2015; published 29 January 2015

Copyright (C 2015 by authors and Scientific Research Publishing Inc.

This work is licensed under the Creative Commons Attribution International License (CC BY).

http://creativecommons.org/licenses/by/4.0/

(c) (i) Open Access

\section{Abstract}

The first classroom experiences are essential to learn how to teach. Anxiety and doubts related to their abilities to teach are the main characteristics that define the novice teachers (Scott, 1995). The aim of the research is to study the educational intervention of the physical education student teachers (PEST) and their evolution in the period of the preparation training for the professional life from the perspective of teaching styles that they used. Participants who had accepted to participate in this study were physical education students registered at high institute of sports and physical education in Tunisia (ISSEP). All were young males (21 \pm 1 years old) enrolled in an introductory course to professional life, what we call in Tunisia introductory course to practice pedagogy (introductory practicum applied to pedagogy), where share of the curriculum was of the last year of the fundamental of physical education license. This professional learning activity was held in three high schools with mixed age classes (12 - 14 years old pupils) of a rural area in Tunis. The activity lasted two semesters, four hours per week on Tuesday or Thursday for a cumulative total time of 116 hours of teaching. A macro analysis of the results showed that the preferred styles by PEST were command style, practical style and reciprocal style (Table 1). The micro analysis of each of these styles indicated that ten sessions $(62.5 \%)$ had been conducted with the command style of teaching, four (25\%) with the practical teaching style, and only two (12.5\%) with the reciprocal teaching style. Finally, this study shows that the plurality teachers prefer teaching with the style of command that represents the lower limit of individualization; autonomy and creativity as the teacher centers his intervention on its own activities and not on the activity of the student.

\section{Keywords}

Teaching Style, Evolution, Student Teacher, Internship, Physical Education 


\section{Introduction}

"What distinguishes man as a species is not only his ability to learn, but also that of teaching".

(Bruner, 1984)

One of the fundamental issues of education is to know what is teaching and what is best way of teaching (Willingham, 2007). The first classroom experiences are essential to learn how to teach. Anxiety and doubts related to their abilities to teach are the main characteristics that define the novice teachers (Scott, 1995). Situations where beginners are having dilemmas reflect a mismatch between the skills acquired in training, their plans or predictions of what will be their actions in the classroom, and knowledge built during the actions in the classroom. Concerning the study of activity, we can not neglect the essential theme regarding the relationship between theory and practice (Bali, 2005).

Thus, the training course shows that a great professional of physical education is distinguished by the quality of his practical application, through his understanding of didactics and methodology used to transmit contents (Carlier \& Fox, 2007; Bali, 2013; Bali et al., 2014).

However, preparing quality practices also requires prior consideration at a theoretical level that involves the selection of activities to do, the best temporizing and its justification in the session. Without this preliminary theoretical reflection, and based on the design of human individuality of each trainer, the practice does not transmit all his educational power; the same way that the practical application continues to be a source of reflection of our beliefs as a teacher, no misinterpretation of the social progress of the physical education teacher can spoil the only observatory of human event which arise during the motor practice (Bali, 2005; Mead \& Fox, 2007).

In this perspective and according to Wilfred Carr \& Stephen Kemmis (1988) "Teaching can not be understood only by the reference framework during which assistants find meaning in what they do. The teachers could not even begin to 'practice' if they had not any theoretical knowledge about the situation in which they operate and some ideas on what should be done. In this sense, the teachers who relate to the practice of education must have prior theory which structures their activities and which guides their decisions” (Carri \& Kemmis, 1988).

However, we can not talk about teaching without referring to the notion of teaching style. Each discipline corresponds to a dominant teaching style. This style will be authoritarian in mathematics, in French or in history and geography, and in a more laxed way in physical education, music education and drawing (Roiné, 2009). Or, can we say that each discipline is correlated to a particular style of teaching, or shall we think that there is a gap between the designs of today, and the teaching styles of a novice teacher of "yesterday", who refers to the models he lived and that proved to be effective. This idea is similar to that of Yelnik (2005), a school model prevailing in the representations and the practices of teachers. This model is mainly characterized by a tension on the "lecture" mode for the transmission of knowledge, exclusion of the psychic dimensions, and a difficulty in rethinking the group dimensions in the educational situations, three characteristics that appear to be linked (Mendel, 2002).

But for many, the so-called traditional teaching approaches are no longer adapted to today's youth. If it is evident that educational innovation can positively influence the motivation and enjoyment of students, this innovation should not overshadow the existing and effective teaching processes. Knowing and taking into consideration the representations, the likes and dislikes of our students seems also to be as educationally important as the need to develop them, to go beyond them, to appreciate again or to recognize the former ones (Beunard, 1999).

Moreover, the period practical training in immersion in a school setting, expected in most training programs initial to teaching, for many students is a critical stage of their pre-professional development (Altet et al, 2002; Molina \& Gervais, 2008; Bali et al., 2014).

Consistent with the foregoing, Serres et al. (2006) confirm that this moment of training is often perceived by the student as the one where he is really learning.

\section{Conceptual Framework}

\section{The Teaching Style}

To start, Altet (1994) defines the teaching style as the dominant way of being, making relations and teaching. In addition, he defines the style of teaching as a personal way to establish the relationship with students, to manage a classroom or a learning group, without prejudice of methods or techniques used. The teaching style is, according to Altet (1997), a combination, an interaction between three dimensions: personal style, relational style and 
the teaching style. Similarly, Legendre (2005a) defines the style of teaching as the configuration of behaviors and attitudes that characterize a teacher in terms of components and various relationships of the educational situation. In another vision, Mosston and Ashworth (2002b) defined the style of teaching as a structure of the teacher's behavior or the whole of decisions taken during the teacher-student meeting that produce a particular way of learning. Finally, Sara Ashworth (2010) described the style of teaching as an action plan that defines the interaction of specific decision between the teacher and the learner in order to develop specific goals associated with subjects and behaviors.

According to Raynal and Rieunier (2009) teaching aims to organize learning situations and and to increase the opportunities to learn in a stimulating environment. Each individual in a teaching situation naturally develop a style of his own and brings him into a limited space-time to establish interpersonal relationships conducive to student development and to learning (Raynal \& Rieunier, 2009). Indeed, several theoretical models have been developed to date to try to identify the different styles used by teachers (Banville, Richard, \& Raîche, 2004). One of the models that have had a significant impact in the field of teaching physical education is that of Therer, and Willemart (1983).

By freely drawing on the work of Robert Blake and Jane Mouton (1964) in management, Therer and Willemart (1982) attempted to identify and describe four representative teaching styles observable teaching practices. These styles are defined from a two-dimensional model that combines two attitudes of the teacher: attitude regarding the material and attitude regarding the learners. Each of these attitudes is expressed in varying degrees, weak or strong, disinterest or interest. The combination of these two attitudes is used to identify the four basic styles such as:

We are still within the different teaching styles, the environment in which the SPE sessions can take place (stadium, gymnasium, outdoor, etc.) hardly lends itself to certain models of teaching where the motor dimension is absent, for example that of the role play or that of the class meeting (Joyce et al., 2004). Physical Education is defined as a discipline which requires the implementation of bodily practices in various physical activities (Legendre, 2005a; MEQ, 2005). In this sense, a selection of educational models for the SPE is necessary for the study of the act of teaching of this discipline. Mosston and Ashworth (2002a) highlight eleven teaching styles that apply specifically to the act of teaching physical education (Banville, Richard, \& Raîche, 2004). However, unlike the work of Jean and Claude Therer Willemart (1983), the model of Mosston and Ashworth (2002b) does not group the styles (or models) of instruction into four families; it classifies them rather a continuum according to their reproductive orientation (teacher-centered learning) or productive (student-centered learning).

The range of teaching styles Mosston and Ashworth gives researchers a framework for the systematic analysis of teaching and learning in the field of physical education. "The range of teaching styles" that defines the different options and styles available depending on the chosen decision structure includes 11 styles: Command (A), Practice (B) Reciprocal (C), Auto-verification (D) inclusion (E) guided tour (F), convergent Discovery (G), divergent production (H), Individual Program (I), student Initiative (J) Self-education (K).

The eleven styles are distributed along a continuum according to the importance of responsibility in decision making; style "Command (A)" leaving the teacher (E) all decisions while the style "Auto Learning (K)" leave it to the student to decide for him/herself. Styles can be divided into two subgroups, the "reproductive styles" (A to D) and "productive styles" (E K). The "reproductive styles" have common characteristics to present content to teach the student using, for example, a demonstration or an image. The student can then attempt to reproduce in as few mistakes as possible. The main requirement at the cognitive level is memorization of the model to reproduce the technical elements, rules, etc.

"Productive styles" in turn encourage students to produce and discover for themselves the content and the necessary skills (Mosston \& Ashworth, 2002a).

Teaching styles are made from different levels of decision-categories. Mosston and Ashworth (2002a) propose a gradation of teaching styles depending on the division of responsibilities: those granted to the teacher and those granted to the student (Bélanger, 2008).

The purpose of this research, which falls within the scope of the teaching of the physical activity and sports (APS), is the analyze of the educational intervention of the student teachers and their evolution in the period of the preparation training for the professional life from the perspective of teaching styles which they used. According to Mackinnon (1987), who relies on the work of Fuller and Brown (1975), four types of concerns successively affecting the trainee teachers during their initial internship. First, before their first teaching experience, their concerns would relate to difficulties in identifying the role of teacher. Later, their first contacts with students often 
lead them to experience hard times and worries affecting their immediate survival as professionals (Bali et al., 2014). Then, confronted with the limits of their work, the young teachers tend to focus mainly on issues of approaches, styles and teaching methods. Finally, having overcome the first obstacles, they would gradually become interested in their practices, the quality of learning and social and emotional needs of their students. If one relies on this developmental model, we can assume that these are mainly the first types of concerns that affect students during their induction training.

Thus, we wonder about the impact of these concerns which are characterizing the student teachers during their initial training on the teaching style used.

- What are the most preferred teaching styles of the $\mathrm{S} / \mathrm{T}$ ?

- Is there any evolution in the teaching style used by the S/T?

- This evolution is-it intra or inter style?

\section{Method and Data Collection}

\subsection{Study Protocol}

This qualitative study explored the PESTs' teaching style and their evolution over time. It identified and describes the styles used by the PESTs. In this section, we present the different steps of our methodological approach.

\subsection{Procedure}

Permission to conduct the current study by the University was Granted Institutional Review Board, the Tunisian Ministry of sports.

The researchers visited the PESTs in their respective schools in order to present the purpose and design of the research and obtain written informed approval.

\subsection{Participants}

The participants in this empirical study were 8 PESTs. All participated in this study were voluntarily.

The PESTs had accepted to participate to this study were registered at ISSEP. All were young males (21 \pm 1 years old) enrolled in an introductory course to professional life, what we call in Tunisia introductory course to practice pedagogy (introductory practicum applied to pedagogy), that share of the curriculum is of the last year of the fundamental of physical education license. This professional learning activity was held in three high schools with mixed age classes (12 - 14 years old pupils) of a rural area in Tunis. The activity lasted two semesters, four hours per week on Tuesday or Thursday for a cumulative total time of 116 hours of teaching.

Participants were not remunerated for participating in the research. They were not informed of the purpose and design of the research and written informed consent obtained from Each of Them. The research proposal approved by the ethics was board of Sports Ministry.

In this study, we will attempt to verify through semi-structured interviews and video recordings of student teachers (E/S) of the main issues. In addition, the analysis of its questions, allow us to understand the different styles used teachings and developments over the period of the course.

The purpose of this research is to determine the evolution of the most used by eight student teachers lessons styles during a physical education session, while highlighting the complex and non-predictable the development of the activity of trainees teachers.

Two categories of data will be used: In a first, the video recording data of trainee teachers in the various contexts of physical education session. In a second instead of verbalizing data during semi-structured interviews to capture the sense of the activity and the style used by the player (which he referred, felt, learned in life situation).

To achieve these catch data, a special technical device was developed. It allows not only to record the verbal and non-verbal trainee but also to gather together during the session, comments "live" from the teacher.

The verbatim from the transcript of the speech of trainee teachers at the two catch data (first and second observation observation) was treated by analysis of categorical content type. The procedure for this assay is described by two points: 1 ) the cutting of the sense transcript in units; 2) the categorization process.

The counting of speech trainee teachers allowed us to prepare the grid for identifying teaching styles $\mathrm{I} / \mathrm{O}$ and the statistical tool "Kh 2" used to analyze the evolution of different teaching styles. 
For each participant, two sessions constituting a full teaching-learning situation (beginning and end) were observed. The third parameter to the duration of the session since according to Banville et al. (2004), it may affect the use of teaching styles by teachers. It was therefore determined that this study would focus on the observation of more than 40 minutes teaching sessions. Finally, the fourth parameter refers to postulate Mosston and Ashworth, (2002a) that there is a change in teaching style based on the number of students per class. In this regard, the number of students making up the classes observed is fixed in a range of (25 to 32).

\subsection{Data Collection Process}

\subsubsection{Procedure}

First to start this work, the permission was granted by the Director of ISSEP Tunis and teachers to realize the current study. Then, the researcher collected the PESTs to explain them the stages of the study.

\subsubsection{Participants}

Participants in our qualitative study were 8 PESTs requested the Higher Institute of Sport and Physical Education (ISSEP) Tunis (there are only 3 ISSEP Tunisia each of which has its own modality of teaching practice). All PESTs who participated in this study, taught in different academic institutions and studied in ISSEP is a public Higher Institute of Sport and Physical Education in Tunisia.

Participants were selected taking into account the location of the land relative to the school and the level taught. They were recruited from a single Higher Institute of Sport (Tunis). The sample of participants consisted of the PESTs (third year, BAC +3) who taught Level 1 and 2 (first year of secondary school and second year). (Bali et al., 2014)

The choice of these criteria was because the PESTs had a compulsory internship in the third year of study and teaching the same level. All participants agreed to start during an informational meeting. Participants were not informed of the purpose and design of the research and the choice of each. The research project was approved by the ethics committee of the Ministry of Sports.

\subsubsection{Video Recording}

The collected data related to the practice of PEST's style teaching, was constituted by a double video recording. The class and the teacher were filmed in a fixed plan. Concerning the second mobile camera allowed to follow closely the teacher and to collected the totality of the teacher and the students' interactive behaviour. The notetaking of the teacher of the verbal intervention as and when his location does not allow the video recording closely.

About the gymnastics teachers coaching practices giving wide shot to see all the events that take place in the classroom, we retained: All the situations where the teacher talks to the class with a didactic purpose, when it comes to knowledge and learning. It is in these moments that are exchanged in part the basis of implicit and explicit didactic contract.

We collected all the verbal speeches, the manipulations, the mimics and the motor actions of the gymnastic teachers.

\subsubsection{Analysis Data Processing of the Observation Sessions}

For this step is proposed to categorize the intervention through the analysis of the video data of each session. It is therefore based on the observation of tasks constructed by the teachers, the teacher and the students' behaviours, and the collection of collective interactions and those localized to a student or group of students. We started in a first step: by the video recording of the practical gymnastic sessions and their transcripts. To evade being overwhelmed by the data, we made a transcription as and when recording to situate the notes taken by the researcher during the video recording sessions. The gymnastic sessions are filmed in their entirety by the researcher who does not intervene during the session. It is to film all the didactic interventions of the gymnastics teacher. The camera is directed on the teachers and the students to enable an optimal observation of the interactions between the three poles of the triangle, which constitutes the didactic system (Chevallard, 1988) namely the teacher pole, the knowledge pole and the learning pole.

Finally, the topic of this study has not been announced to the teachers before the observation of the practical gymnastics sessions in order not to manipulate their teaching practices.

This first level of transcript gives grow to a first macro-analysis which allows regrouping data related to prac- 
tical sessions according to the study moments which were therefore able to be identified: the first encounter with the knowledge, the work of the technical and the evaluation. This first step is essential for the elaboration of a grid in order to categorize the didactical interventions of participants.

The results will be presented in a grid elaborated by the researchers and presented in Table 1 .

"A posteriori" analysis of the recorded PE sessions is another step which is based on the whole data collected during the observation of the recorded gymnastics practical sessions: the observation of the behaviour of the teacher interacting with his students during the session. We elaborated the grid observations of the PESTs' didactic practices through the observation of the teacher behaviours to characterize the didactic practices of Tunisian PEST (Postic \& De Ketele, 1980) which led to a corpus of 180 pages. This grid was constructed respecting two essential elements of this research namely: i) a corpus of 180 pages of the transcript obtained from the observations (exactly of 16 gymnastics sessions observed by the researcher); ii) The hypothesis of this research.

\section{Result}

Following the results obtained in Table 1 for the variable of Instructional styles frequency of use, we see that the eight student teachers conducted at the first observation (OBS1) a total of 2178 repetitions of which 835 refer the style of teaching per order, which gives us a percentage equal to $38.34 \%$ compared to the sum of the frequencies of repetitions of all styles, 728 practical teaching style which brings the percentage of $33.42 \%$ and $615 \%$ in reciprocal teaching style with a percentage of $28.24 \%$. Whereas at the second observation (OBS2), they realized a total of 2108 repetitions of which 834 belong to the order by teaching style, which gives us a percentage equal to $39.75 \%$, 756 repetition of the practical teaching style wearing the percentage of $35.55 \%$ and 518 to the reciprocal teaching style that contains a percentage equal to $24.70 \%$.

Figure 1_shows that the teaching style of command was the most used style by PEST (835 repetition) in the first observation. Then, we find the practical teaching style (728 repetitions) followed by the reciprocal teaching style with 615 repetitions. Regarding the second point, there is always the teaching style per order on top of teaching styles with a slight decrease in the frequency of repetitions from the first one. This allows us to move the

\section{teaching style}

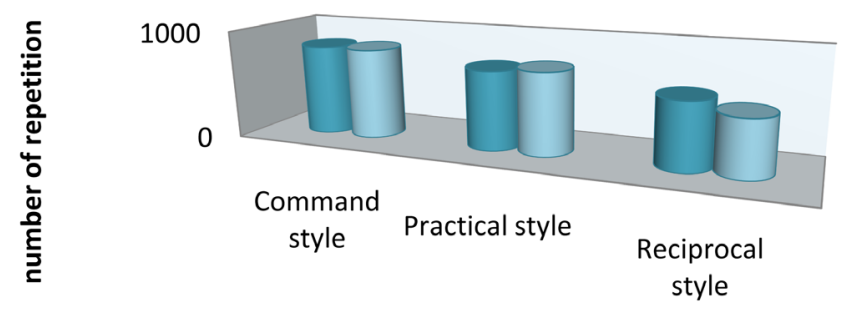

\begin{tabular}{|l|c|c|c|}
\cline { 2 - 4 } \multicolumn{1}{c|}{} & Command style & Practical style & Reciprocal style \\
\hline$\square$ Observation1 & 835 & 728 & 615 \\
\hline 口Observation2 & 834 & 756 & 518 \\
\hline
\end{tabular}

Figure 1. Teaching style adopted by ST.

Table 1. Frequencies and percentages of use of teaching styles Mosston and Ashworth (2002b) at the two observations.

\begin{tabular}{|c|c|c|c|}
\hline \multirow{2}{*}{ Style } & \multicolumn{2}{|c|}{ Total $=\sum(\mathrm{E} 1+\mathrm{E} 2+\mathrm{E} 3 \cdots \mathrm{E} 8)$} & \multirow{2}{*}{$\mathrm{X}^{2}$} \\
\hline & OBS1 & OBS2 & \\
\hline Command & 835 (38.34\%) & 834 (39.75\%) & \multirow{4}{*}{7.692} \\
\hline Practical & 728 (33.42\%) & 756 (35.55\%) & \\
\hline Reciprocal & $615(28.24 \%)$ & $518(24.70 \%)$ & \\
\hline TOTAUX & 2178 & 2108 & \\
\hline
\end{tabular}


majority of trainee teachers (E/S1, E/S2, E/S3, E/S4 and E/S6) adopt a leadership attitude and has some authority, so they chose to teach with a control style for fear of losing control and mastery of the class. The teacher adopting the style of teaching per order therefore seeks to shape student behavior by tracing his own experiences.

Looking at Figure 2 showing the items of the command teaching style, we see that the control of exercises (257 repetitions) and orders (172 repetitions) are the most items used by the PEST at the first observation. This allows us to say that the teacher takes all the decisions alone as orders for fear of losing control and mastery of the class. They seek to maintain a certain order during the session for the purpose of booking a certain distance between the "young" teacher and the students, so that they see it as a real teacher, not as a "friend".

Figure 3 shows the items of command teaching style. It is found that the control of the exercises (217 repetitions) and the orders (188 repetitions) are the most used items by student teachers at the second observation.

\section{Command style}

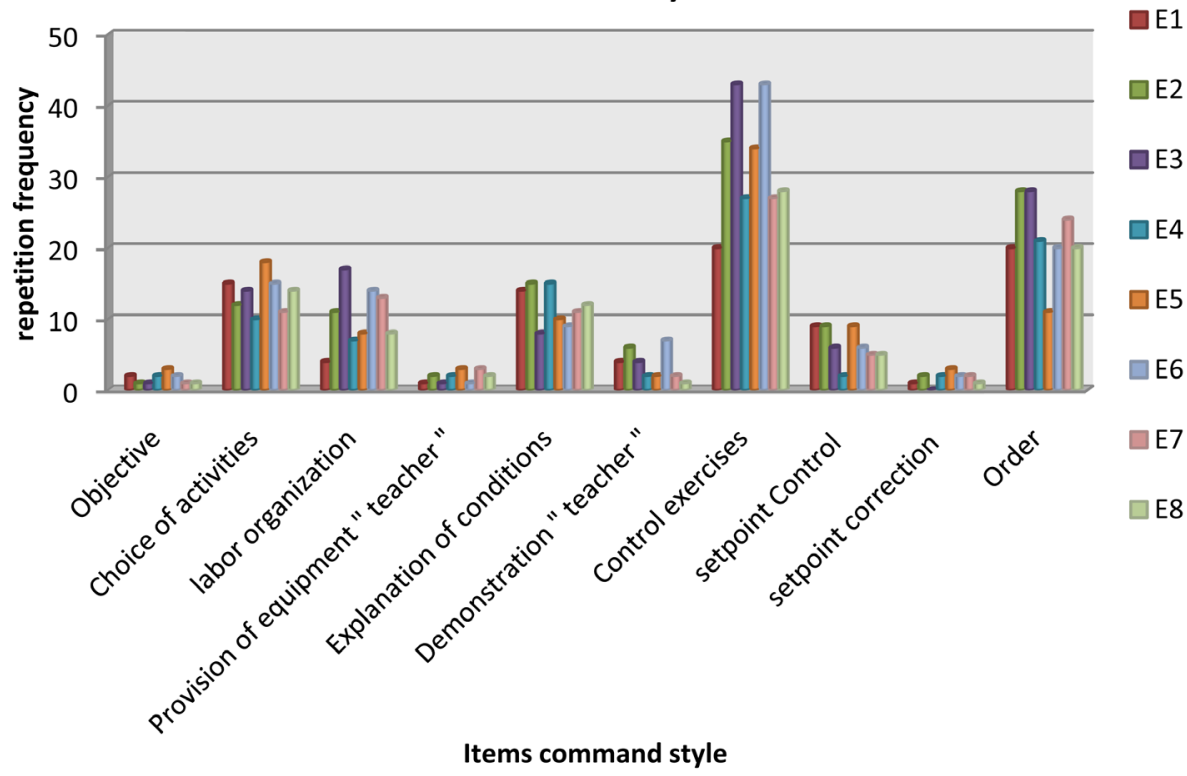

Figure 2. Teaching style command "first observation".

\section{Command style}

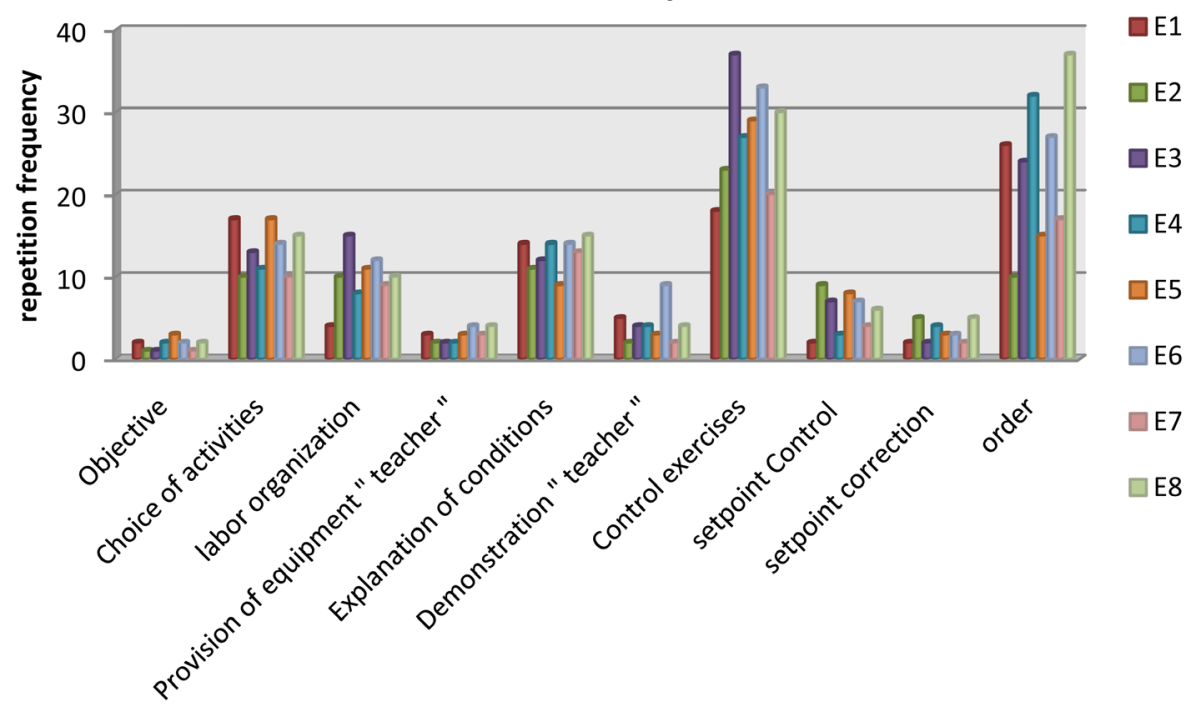

Items commad style

Figure 3. Command teaching style "second observation". 
These two items are present more frequently than other items with a decrease in the frequency of repetitions on the control of exercises and increase the frequency of repetitions from the orders in the second observation. This allows the teacher to say that adopting the command style of teaching considered rather as an expert in the field of theoretical knowledge, shall adopt a leadership attitude and has some authority in the classroom.

As shown in Figure 4, the most used items of practical teaching style, used by student teachers at the first observation were the control of exercises with 255 repetitions followed by activities (109 repetitions). This allows saying that the student teacher gives more autonomy and more students liberties. It encourages them to live their own experiences and he abandoned the activity and the objective elements to greater interest in student learning.

Looking at Figure 5, which shows the items of the style of teaching practice during the second observation, we find that the exercises control with (227 repetitions) and choice of activities (107 repetitions) are the most used

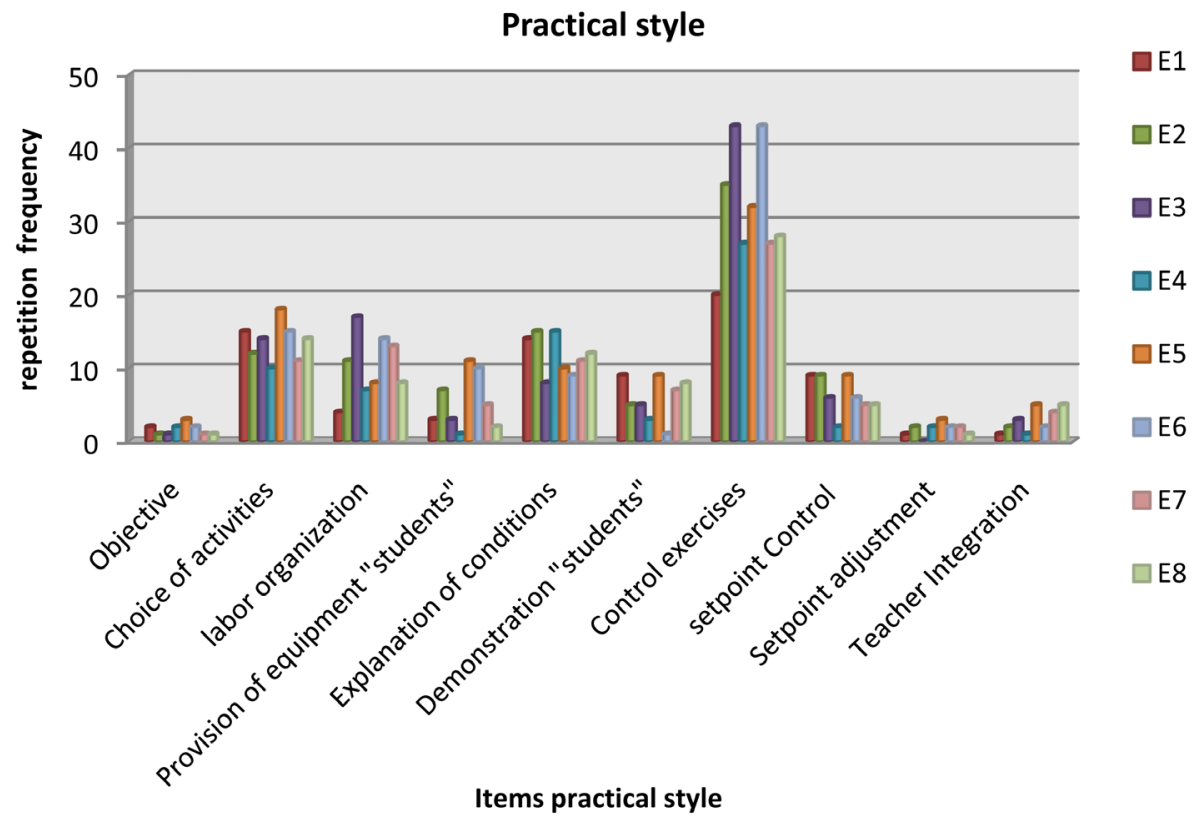

Figure 4. Practical teaching style "first observation".

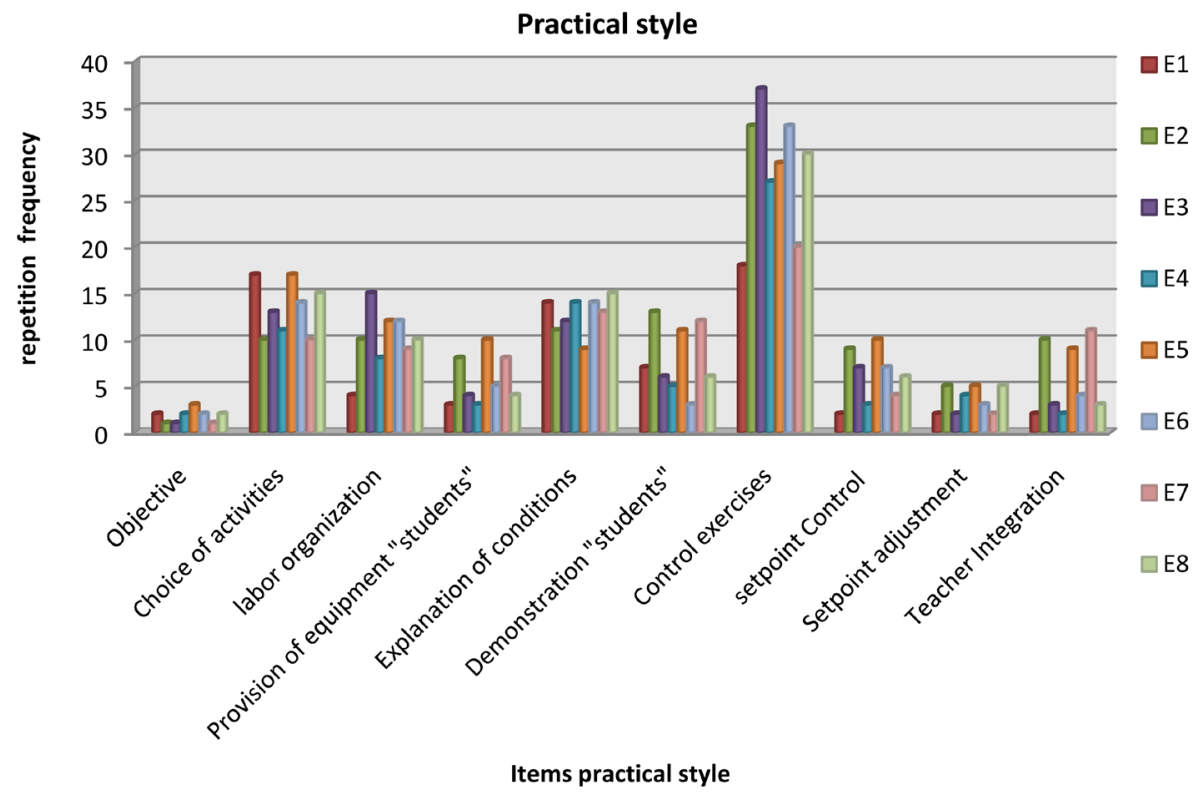

Figure 5. Practical teaching style "second observation". 
items from PEST at the second observation. Compared with the results of the first observation, these two items showed a decrease in the frequency of repetitions from the control exercises also by the choice of activities during the second observation. This allows us to say that this style is to facilitate the exploration of specific actions and reactions of students by promoting their personal initiatives.

Looking at Figure 6 which represents the items of reciprocal teaching style, we see that the choice of activities (109 repetitions), the teacher's stimulation (105 repetitions) and the organization of work (94 repetitions) are the most items used by the student teacher at the first observation. This allows saying that the teacher gives more autonomy and more students liberties. It encourages them to live their own experiences and likes facilitate exploration of own actions and reactions of students.

Figure 7 shows items representing the reciprocal teaching style during the second observation. We find that the explanation of the exercises (102 repetitions), choice of activities (107 repetitions) and work organization (79 repetitions) are the most used items from PEST at the second observation. This allows us to say that this style allows the PEST to manifest feelings of insecurity and doubt that any beginner can try, too, this style is to facilitate the exploration of own actions and reactions of students and encourages personal initiative.

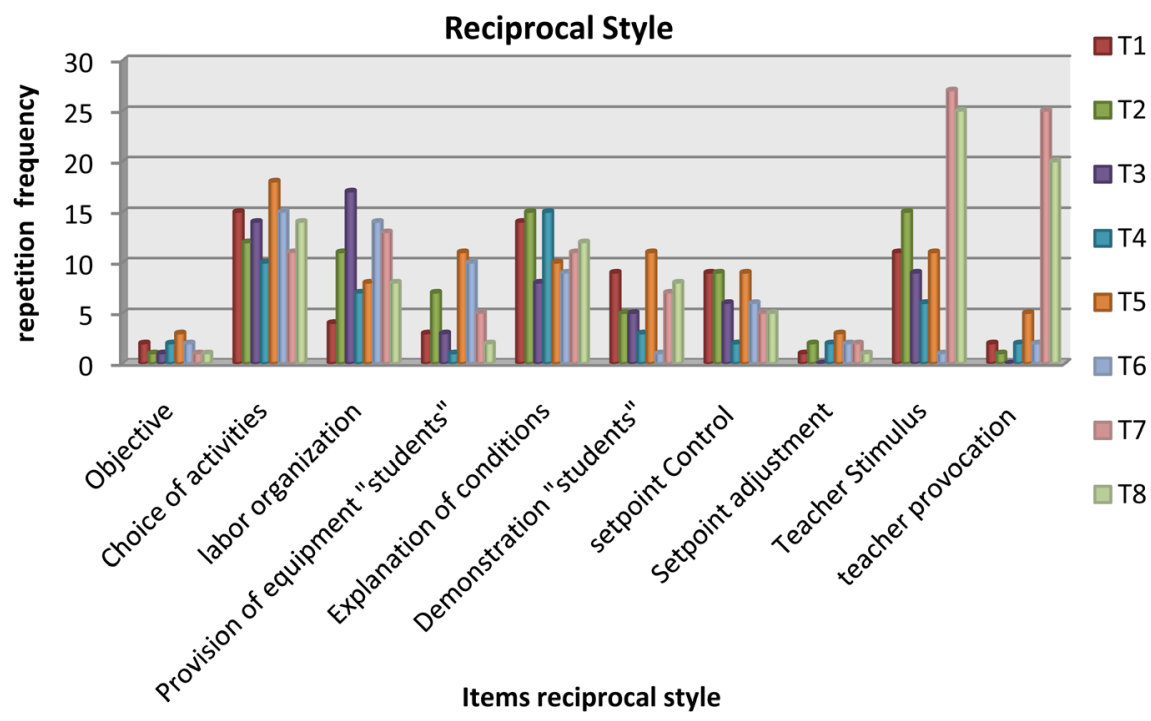

Figure 6. Teaching style reciprocal "first observation".

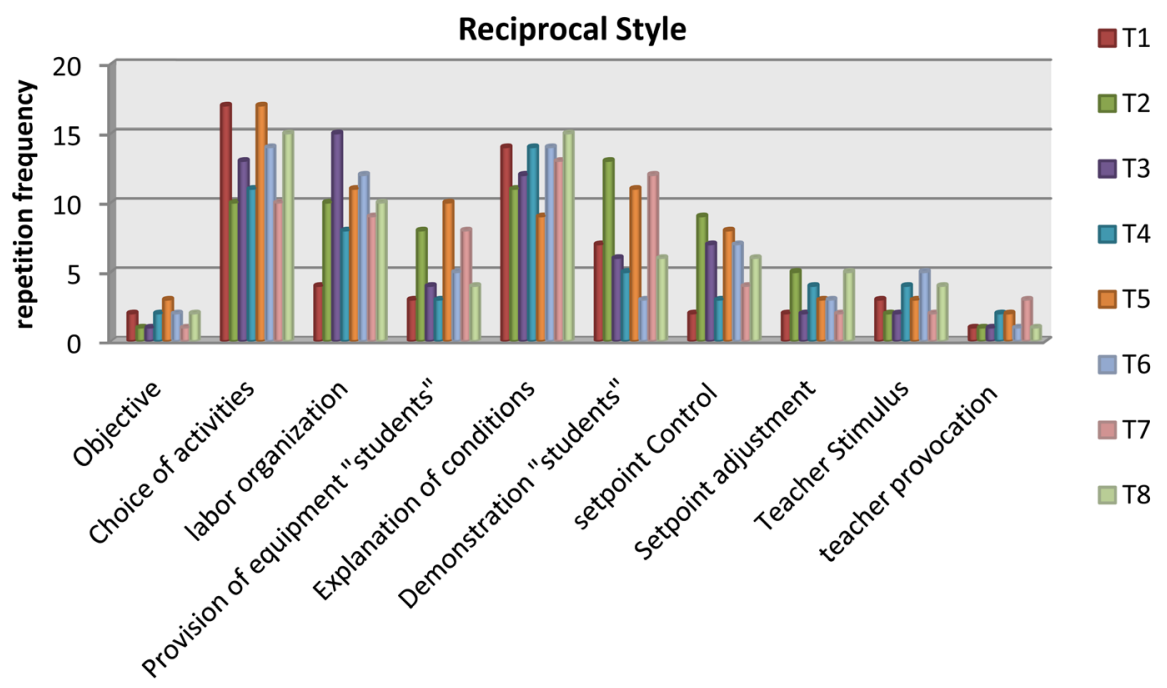

Items reciprocal style

Figure 7. Teaching style reciprocal "second observation”. 
Following the results obtained at Figure 8 for changes in frequency repetitions of items of different teaching styles during the first and second observations of all of all teachers, we see that the integration teacher with the group (25 repetitions) and the disposal of material by the teacher (18 repetitions) are the least used items for different teaching styles, while the control exercises (427 repetitions) and orders (263 repetitions) are the most popular items from the student teachers during the first and second observation. They have completed over number of repetitions than other items in the two observations with an increase in the frequency of repetitions in the control exercises also from orders in the second observation, which allows us to say that trainee teacher takes all the decisions alone as fear of losing control orders and mastery of the class.

As shown in Figure 9, we see that the control of exercises (200 repetitions) and orders (117 repetitions) are the most used items in the first observation for the styles of the teachings of all PEST, which means, in relation to these results, that the majority of teachers seeking to maintain a certain order during the session for the purpose of booking a certain distance between the "young" teacher and students in order they take for a true teacher and not as a "friend".

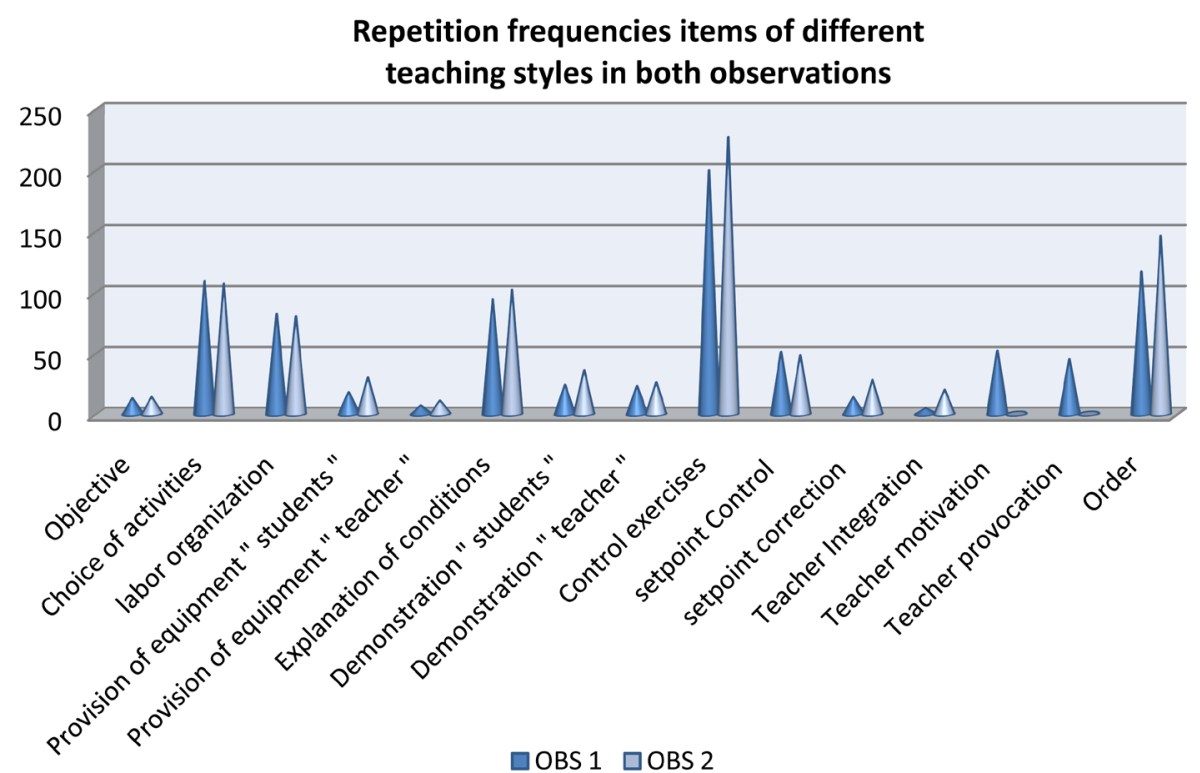

Figure 8. Frequency of items repetitions of different teaching styles during the first and second observations of all teachers.

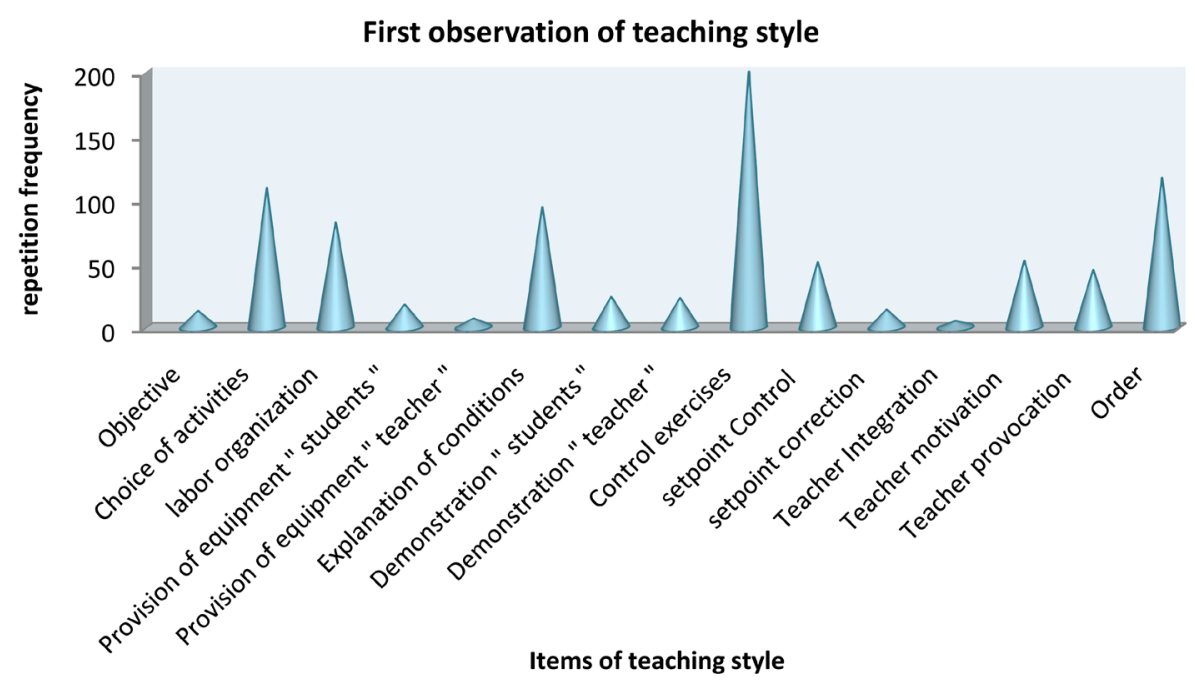

Figure 9. Changing Items styles teachings of all the trainee teachers. 
As shown in "Figure 10", we see that the control exercises (23\%) and orders (14\%) are the most used items in the first observation for the styles of the teachings of all trainee teachers, while the teacher's integration is virtually absent (0\%), which means, in relation to these results, the majority of teachers seeking to maintain a certain order during the session with the aim to reserve a certain distance between the trainee teacher and students in order they take for a true teacher and not as a "friend".

Figure 11 shows the frequencies of teaching style items in the second observation. We see that the control of exercises has the most repetitions (204) and orders (120 repetitions) are the most used items in the second observation for the styles of the teachings of all PEST. It confirms that almost of PEST look for maintaining order during the physical practical session.

Looking at Figure 12, there is still that control exercises (26\%) and orders represent (17\%) most popular items at the second observation for the styles of the teachings of all PEST which means, in relation to these results, the majority of teachers to adopt an attitude of leadership and exert some authority in the classroom. The teacher adopting teaching style items per order therefore seeks to shape student behavior by tracing his own experiences.

\section{First observation of teaching style}

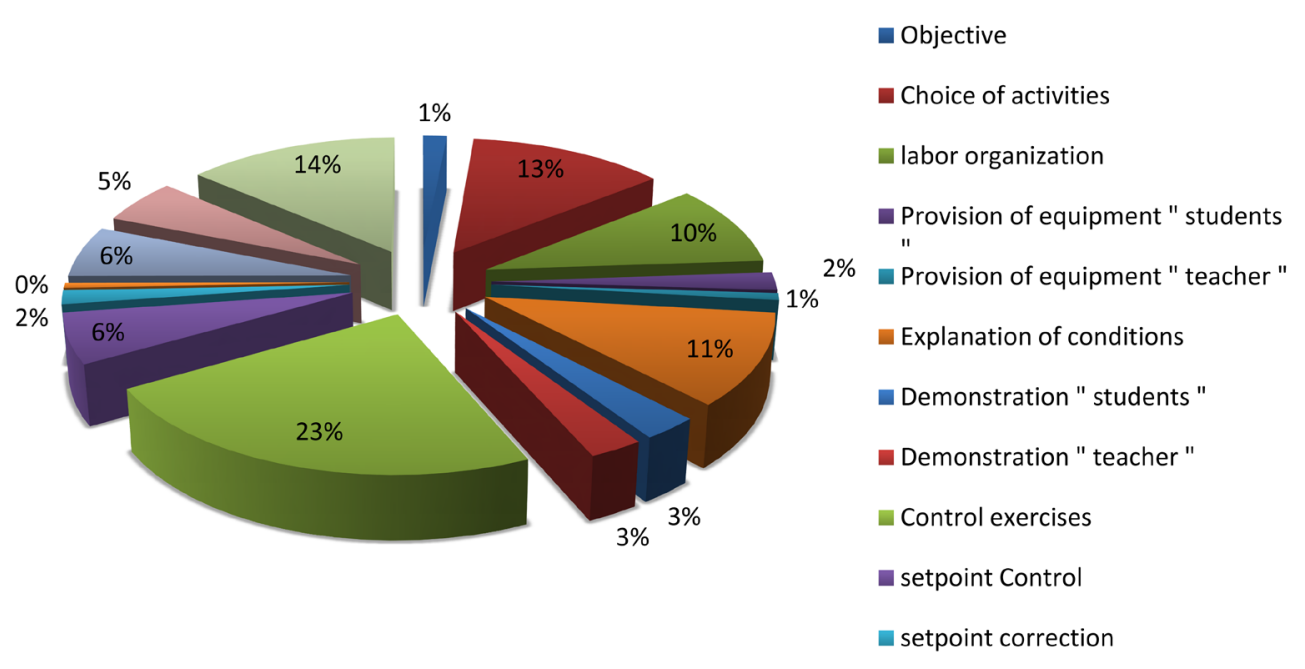

Figure 10. First observation of teaching style.

Second observation of teaching style

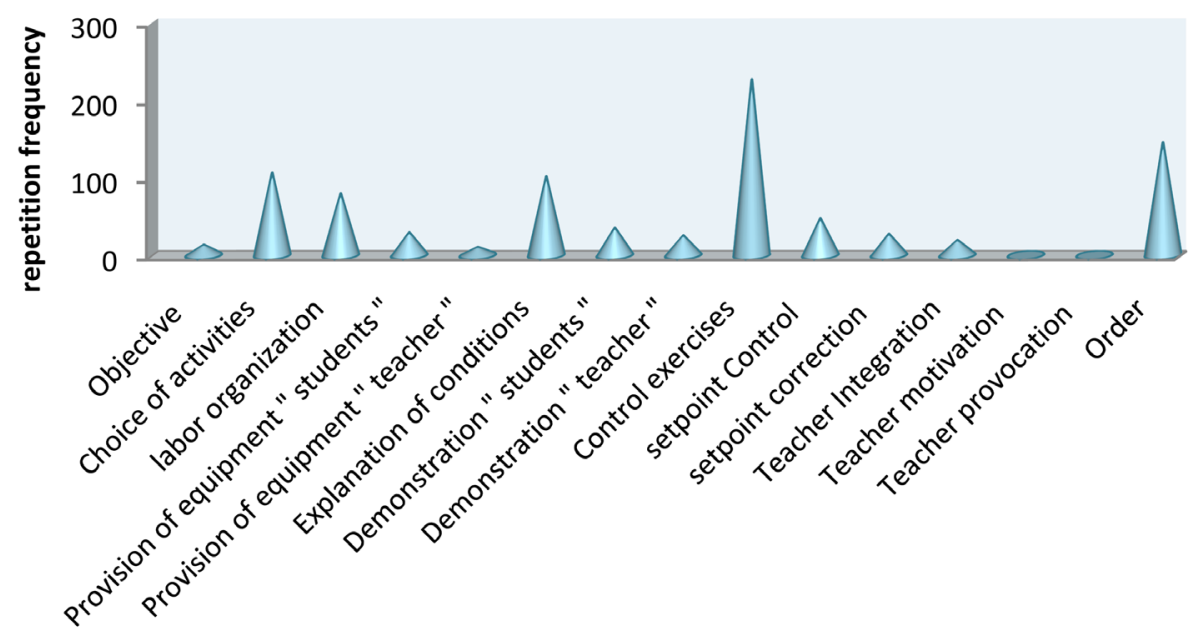

Items of teaching style

Figure 11. Frequencies of teaching style in second observation. 


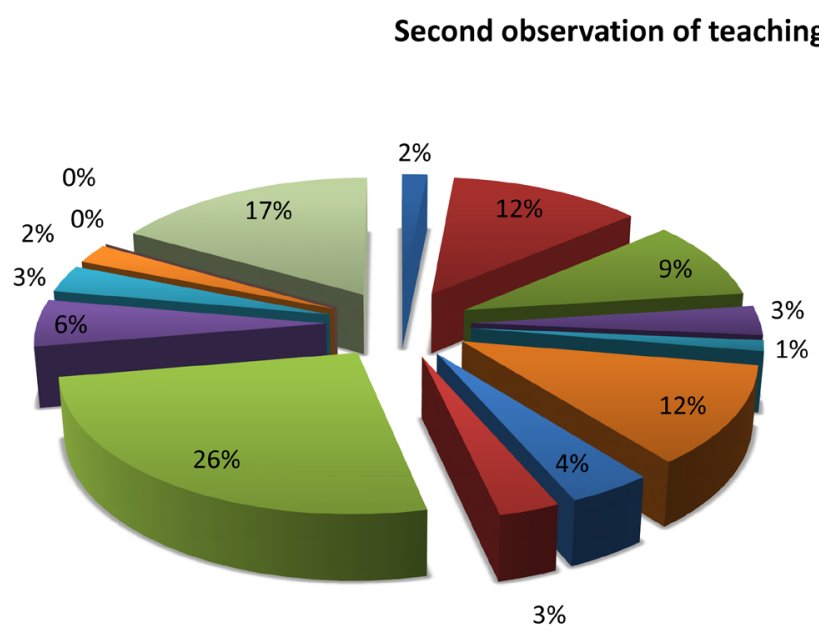

- Objective

Choice of activities

- labor organization

- Provision of equipment " students "

- Provision of equipment " teacher "

- Explanation of conditions

- Demonstration " students "

- Demonstration " teacher "

- Control exercises

- setpoint Control

- setpoint correction

- Teacher Integration

- Teacher motivation

Teacher provocation

order

Figure 12. Second observation of teaching style.

\section{Discussion}

Before analysis it is important to remember the parameters of the study. Each of the eight PESTs has been observed in a teaching-learning situation involving two sessions on two different physical activities. The data presented relate to the observation of 16 sessions on individual physical activities. During these 16 sessions, the teachers presented students with a total of 65 learning activities. The individual activities are racing speed, shot put, MCP (fitness test), Jump languor and gymnastics.

The directory studies on the model of Mosston and Ashworth (2002a), which has eleven teaching styles located on a continuum ranging from the reproductive style "command" to the most productive style "self-education" reveals and at the level of the school environment, physical education teachers are characterized by a fairly prescriptive teaching style in which learners are encouraged to apply guidelines rather than actively participate in the development of their learning (Wallonia Frederick, Gribomont, \& Cloes, 2009; Kulinna et al., 2003).

However, the results of this study demonstrate a change in teaching styles from the student teachers "command, practical and reciprocal" always with the dominance of command style.

This research aimed to study the use of teaching styles and trends in physical education student teachers with the model of teaching styles Mosston \& Ashworth (2002a). This theoretical model offers eleven teaching styles cue points on a continuum ranging from the reproductive style to the most productive style. The most reproductive style does not leave any decision to the student so that the most productive style leaves him all the decisions at a learning activity. Two research hypotheses were formulated: 1) dealing with the most used style by trainee teachers during the internship period; 2) that concerning the verification of degrees of changing styles of teaching trainee teachers.

A macro analysis of the results showed that the preferred styles by PEST are "command teaching style" as shown in Table 1 "practical teaching style" and "reciprocal teaching style". Table 1 shows the frequency of use of each of these teaching styles in the teaching-learning situations.

Following the results in Table 1 for the variable teachings of styles frequency of use, it is found that the sum of the trainee teachers have realized at the OBS1 a total of 2178 repetitions of which 835 refer to the teaching style in order to give us a percentage equal to $38.34 \%$ compared to the sums of the frequencies of all styles rehearsals 728 practical teaching style which brings the percentage of $33.42 \%$ and 615 to the reciprocal teaching style with a percentage of $28.24 \%$.

Following the results obtained in Table 1 and Figure 1 for the variable of learning styles using frequency is found that the sum of ST achieved at the OBS1 a total of 2178 repetitions of which 835 refer to the style " command teaching style" (38.34\%), 728 to the "practical teaching" style (33.42\%) and 615 of the "reciprocal teaching” style (28.24\%).

Whereas at the OBS2, they realized a total of 2108 repetitions of which 834 belong to the command teaching 
style is $39.75 \%$, 756 repetitions practical teaching style to be $35.55 \%$ and 518 repetitions the reciprocal teaching style is a percentage of $24.70 \%$ as shown in Figure 1.

The results obtained by the chi-square test indicate that there is a significant difference between the two points with $P<0.05$ (calculated chi-square is equal to $7.692>X^{2}$ th 5.991 ; $\mathrm{DF}=2$ ).

The micro analysis of each of these styles, has led us to a very detailed reading. The observations data were collected from two teaching sessions for each PEST. The results of this study indicate that sixteen sessions (62.5\%) have been conducted with the style of teaching per order, while four (25\%) with the practical teaching style, and only two (12.5\%) with the reciprocal teaching style. According to this result, predominance in the use of control style that includes a pedagogical strategy for reproductive kind is observed.

From Figure 1 and the statistical analysis of data of Table 1, we see that the teaching style of command was the most used style in the first observation, and then there is the style of teaching practice followed by the reciprocal teaching style with 835.728 and 615 repetitions, respectively. Regarding the second point, there is always the teaching style per order on top of teaching styles with a slight decrease in the frequency of repetitions from the first one. This allows us to suggest that the plurality of PEST as shown in Figures 2-4 at the first observation for major of PEST (PEST1, PEST2, PEST3, PEST4 and PEST6) prefer to focus their work on the business, not the student and as shown in Figures 5-7 at the second observation. They adopt an attitude of leadership and positions of power, and eventually they chose to teach with a control style for fear of losing control and mastery of the class. The teacher adopting the style of teaching per order therefore seeks to model the behavior of students.

As shown in Figure 9 and Figure 10, the control of exercises and orders are the most used items in the first and second observation for the styles of the teachings of all PEST. It confirms that almost of PEST look for maintaining order during the physical practical session and tries to be respected by their students by keeping a distance from them. They hope being looked as real teachers

Moreover, the results allow seeing several forms of the act of teaching based on the model Mosston and Ashworth (2002b). First, there is the use of three teaching styles from the model of Mosston and Ashworth (2002b). The three styles of lessons observed are reproductive-type (A-command, B-practical and C-reciprocal) as shown in Figure 1 that do not allow the student to be the learning center. The results of the study, we validate two research hypotheses that the theoretical model of teaching styles easily allows to study the act of teaching natural context.

Furthermore, although the results of Figure 8, Figure 10 and Figure 12 allow such a conclusion, it is necessary to mention some limitations of PEST training. It would be interesting to replicate these results to a larger number of subjects and to assess the impact of personal characteristics of teachers on their teaching styles.

\section{Conclusion}

This study shows that the most of PEST prefer teaching with the style of command that represents the lower limit of individualization; autonomy and creativity as the teacher centers his intervention on its own activities and not on the activity of the student. It seems necessary to us to determine the ideal teaching style to encourage student involvement and hence their learning.

Finally, it is desirable that the results of this study, although reduced in number of topics can serve as a basis for future investigations.

\section{References}

Altet, M. (1994). La formation professionnelle des enseignants. Paris: Collection Pédagogues et Pédagogie, 264.

Altet, M. (1997). Les pédagogies de l'apprentissage. Paris, PUF.

Altet, M. et al. (2002). Formateurs d'enseignants: Quel professionnalisation? Recherche et Formation, 41, 261-274.

Bali, N. (2005). "Theory and Practice” Articulation in the Training of Tunisian Student Physical Education Teachers. Journal Research and Training, 49, 135-150.

Bali, N. (2013). Teachers’ Thought Processes: The Case of Tunisian Gymnastic University Teachers. Creative Education, 4, 158-164.

Bali, N. et al. (2014). The Conceptions of Integration of Tunisian Physical Education Cooperative Teachers and Student Teachers. Creative Education, 5, Article ID: 43922. http://dx.doi.org/10.4236/ce.2014.54037

Banville, D., Richard, J.-F., \& Raîche, G. (2004). Utilisation des 11 styles d’enseignement de Mosston chez des éducateurs 
physiques francophones du Canada. Avante, 10, 32-44.

Bélanger, C. (2008). Les styles d'enseignement et le partage de décisions utilisés par des enseignants en éducation physique du troisième cycle du primaire lors d'une situation d'enseignement-apprentissage. Mémoire de Maîtrise en éducation. Montréal (Québec, Canada), 3, 58-74.

Beunard, B. (1999). Que pensent les lycéens de l’Education Physique? Revue Education Physique et Sport, 280, 76-79.

Bruner, J. S. (1984). Le développement de l'enfant: Savoir faire, savoir dire. Paris: PUF, 1983.

Carlier, G., \& Renard, J.-P. (2007). Plaisir, compétence et réflexivité: La formation continue en éducation physique. Vol. 9964, 265-284.

Carri, W., \& Kemmis, S. (1988). Educators as Action Researchers: Some Key Considerations. 162 p.

Fuller, F., \& Brown, O. (1975). Becoming a Teacher. In K. Ryan (Ed.), Teacher Education: Seventy-Fourth Yearbook of the National Society for the Study of Education. Chicago: University of Chicago Press.

Joyce, B., Weil, M., \& Calhoun, E. (2004). Models of Teaching. Boston, MA: Allyn and Bacon.

Kulinna, P. H., \& Cothran, D. J. (2003). Physical Education Teachers' Self-Reported Use and Perception of Various Teaching Styles. Learning and Instruction, 13, 597-609. http://dx.doi.org/10.1016/S0959-4752(02)00044-0

Legendre, P. (2005b). Les styles d'enseignement et le partage de décisions utilisés par des enseignants en éducation physique du troisième cycle. 12-15.

Legendre, R. (2005a). Dictionnaire actuel de l'éducation (3 éd.). Montréal: Guérin.

Mackinnon, A. M. (1987). Detecting Reflection-in-Action among Preservice Elementary Science Teachers. Teaching and Teacher Education, 3, 135-145. http://dx.doi.org/10.1016/0742-051X(87)90014-X

Mendel, G. (2002). Nouveau millénaire, Défis libertaires. Conférence Autorité et Education à l'Institut Sociologie Psychanalyse (dans prolongement de son ouvrage Histoire de l'autorité). Paris: Albin Michel.

Mosston, M., \& Ashworth, S. (2002a). Teaching Physical Education (5th ed.). New York: Benjamin Cummings.

Mosston, M., \& Ashworth, S. (2002b). Teaching Physical Education (6th ed.). New York: Macmillan College Publishing Company.

Molina, E., \& Gervais, C. (dir.). (2008). Les stages en formation à l'enseignement: Pratiques et perspectives théoriques. Presses de l’Université du Québec.

Raynal, F., \& Rieunier, A. (2009). Pédagogie: Dictionnaire des concepts-clés. Paris: ESF.

Ria, L., Sève, C., Durand, M., \& Bertone, S. (2004). Indétermination, contradiction et exploration: Trois expériences typiques des enseignants débutants en éducation physique. Revue des sciences de l'éducation, 30, 535-554. http://dx.doi.org/10.7202/012081ar

Roiné, C. (2009). Cécité didactique et discours noosphériens dans les pratiques d'enseignement en SEGPA: Une contribution à la question des inégalités. Thèse de doctorat soutenue à l'université de Université Victor Segalen Bordeaux 2.

Scott, L. D. (1995). Successful Beginning Teachers: A Developmental Model of Support and Assessment. Teacher Education Quarterly, 22, 93-105.

Serres, G., Ria, L., Adé, D., \& Sève, C. (2006). Apprend-On vraiment à intervenir en formation initiale? Prémisses du développement de l'activité professionnelle dans les dispositifs de formation en alternance. Revue STAPS, 72, 9-20. http://dx.doi.org/10.3917/sta.072.09

Therer \& Willemart (1982). Encyclopédie de l'évaluation, cité dans A. de Peretti. Liège: Université Liège, 115 p.

Therer, J., \& Willemart, C. (1983). Styles et Stratégies d'enseignement et de formation-Approche paradigmatique par vidéo. Education Tribune Libre, Probio Revue, 2.

Willingham, D-T. (2007). Pourquoi l'enfant n'aime pas l'école. La Librairie des Écoles, 213 p.

Yelnik, C. (2005). Mettre au travail la personne et le groupe en formation. Cahiers pédagogiques Enseigner, un métier qui s'apprend, 435. 
Scientific Research Publishing (SCIRP) is one of the largest Open Access journal publishers. It is currently publishing more than 200 open access, online, peer-reviewed journals covering a wide range of academic disciplines. SCIRP serves the worldwide academic communities and contributes to the progress and application of science with its publication.

Other selected journals from SCIRP are listed as below. Submit your manuscript to us via either submit@scirp.org or Online Submission Portal.
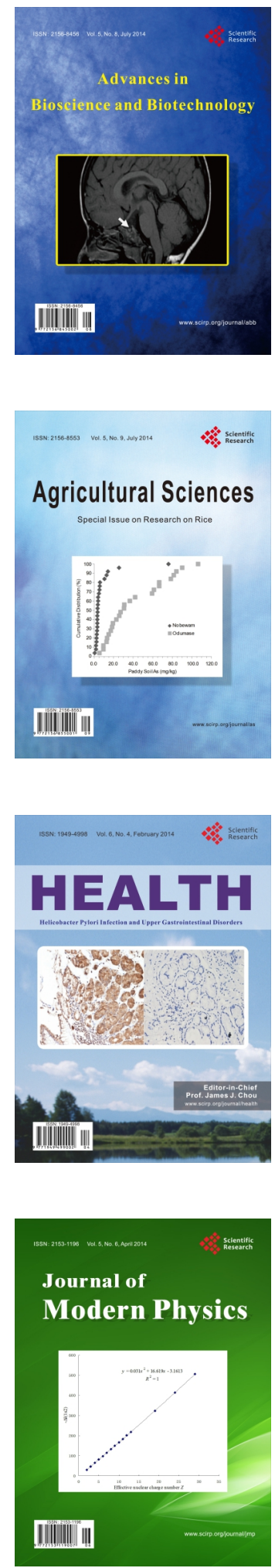
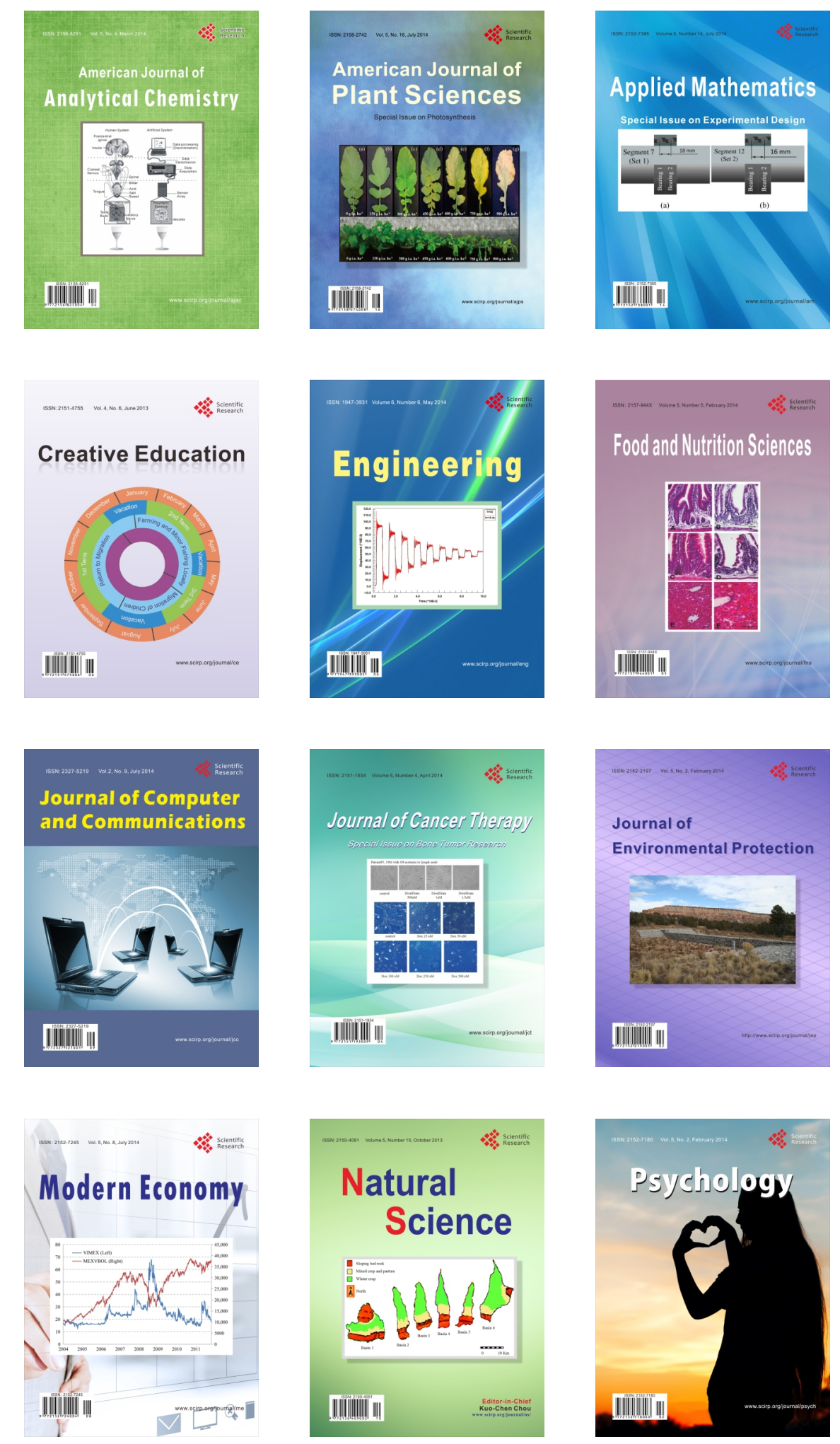